\title{
SYMMETRIZED CONVEXITY AND HERMITE-HADAMARD TYPE INEQUALITIES
}

\section{S. S. DRAGOMIR}

Abstract. In this paper we extend the Hermite-Hadamard inequality to the class of symmetrized convex functions. The corresponding version for $h$-convex functions is also investigated. Some examples of interest are provided as well.

Mathematics subject classification (2010): 26D15, 25D10.

Keywords and phrases: Convex functions, Hermite-Hadamard inequality, integral inequalities, $h$ convex functions.

\section{REFERENCES}

[1] M. Alomari and M. Darus, The Hadamard's inequality for s-convex function, Int. J. Math. Anal. (Ruse) 2 (2008), no. 13-16, 639-646.

[2] M. Alomari AND M. Darus, Hadamard-type inequalities for s-convex functions, Int. Math. Forum 3 (2008), no. 37-40, 1965-1975.

[3] G. A. Anastassiou, Univariate Ostrowski inequalities, revisited, Monatsh. Math., 135 (2002), no. 3, 175-189.

[4] N. S. Barnett, P. Cerone, S. S. Dragomir, M. R. Pinheiro and A. Sofo, Ostrowski type inequalities for functions whose modulus of the derivatives are convex and applications, Inequality Theory and Applications, Vol. 2 (Chinju/Masan, 2001), 19-32, Nova Sci. Publ., Hauppauge, NY, 2003. Preprint: RGMIA Res. Rep. Coll. 5 (2002), No. 2, Art. 1 [Online http://rgmia.org/papers/v5n2/Paperwapp2q.pdf].

[5] E. F. Beckenbach, Convex functions, Bull. Amer. Math. Soc. 54 (1948), 439-460.

[6] M. Bombardelli And S. Varošanec, Properties of h-convex functions related to the HermiteHadamard-Fejér inequalities, Comput. Math. Appl. 58 (2009), no. 9, 1869-1877.

[7] W. W. BRECKNER, Stetigkeitsaussagen für eine Klasse verallgemeinerter konvexer Funktionen in topologischen linearen Räumen, (German) Publ. Inst. Math. (Beograd) (N.S.) 23 (37) (1978), 13-20.

[8] W. W. BRECKNER AND G. ORBÁN, Continuity properties of rationally s-convex mappings with values in an ordered topological linear space, Universitatea "Babeş-Bolyai", Facultatea de Matematica, Cluj-Napoca, 1978. viii+92 pp.

[9] P. Cerone And S. S. Dragomir, Midpoint-type rules from an inequalities point of view, Ed. G. A. Anastassiou, Handbook of Analytic-Computational Methods in Applied Mathematics, CRC Press, New York, 135-200.

[10] P. Cerone And S. S. Dragomir, New bounds for the three-point rule involving the RiemannStieltjes integrals, in Advances in Statistics Combinatorics and Related Areas, C. Gulati, et al. (Eds.), World Science Publishing, 2002, 53-62.

[11] P. Cerone, S. S. Dragomir And J. Roumeliotis, Some Ostrowski type inequalities for $n$-time differentiable mappings and applications, Demonstratio Mathematica, 32 (2) (1999), 697-712.

[12] G. Cristescu, Hadamard type inequalities for convolution of h-convex functions, Ann. Tiberiu Popoviciu Semin. Funct. Equ. Approx. Convexity 8 (2010), 3-11.

[13] S. S. DRAGOMIR, Ostrowski's inequality for monotonous mappings and applications, J. KSIAM, 3 (1) (1999), 127-135.

[14] S. S. DRAGOMIR, The Ostrowski's integral inequality for Lipschitzian mappings and applications, Comp. Math. Appl., 38 (1999), 33-37. 
[15] S. S. Dragomir, On the Ostrowski's inequality for Riemann-Stieltjes integral, Korean J. Appl. Math., 7 (2000), 477-485.

[16] S. S. DRAGOMIR, On the Ostrowski's inequality for mappings of bounded variation and applications, Math. Ineq. \& Appl., 4 (1) (2001), 33-40.

[17] S. S. Dragomir, On the Ostrowski inequality for Riemann-Stieltjes integral $\int_{a}^{b} f(t) d u(t)$ where $f$ is of Hölder type and $u$ is of bounded variation and applications, J. KSIAM, 5 (1) (2001), 35-45.

[18] S. S. Dragomir, Ostrowski type inequalities for isotonic linear functionals, J. Inequal. Pure \& Appl. Math., 3 (5) (2002), Art. 68.

[19] S. S. DRAGOMIR, An inequality improving the first Hermite-Hadamard inequality for convex functions defined on linear spaces and applications for semi-inner products, J. Inequal. Pure Appl. Math. 3 (2002), no. 2, Article 31, 8 pp.

[20] S. S. DRAGOMIR, An inequality improving the second Hermite-Hadamard inequality for convex functions defined on linear spaces and applications for semi-inner products, J. Inequal. Pure Appl. Math. 3 (2002), no. 3, Article 35.

[21] S. S. Dragomir, An Ostrowski like inequality for convex functions and applications, Revista Math. Complutense, 16 (2) (2003), 373-382.

[22] S. S. Dragomir, Operator Inequalities of Ostrowski and Trapezoidal Type, Springer Briefs in Mathematics, Springer, New York, 2012.

[23] S. S. DRAGOMIR, Inequalities of Hermite-Hadamard type for h-convex functions on linear spaces, Proyecciones 34, 4 (2015), 323-341. Preprint RGMIA Res. Rep. Coll. 16 (2013), Art. 72 [Online http://rgmia.org/papers/v16/ v16a72.pdf].

[24] S. S. Dragomir, P. Cerone, J. Roumeliotis And S. Wang, A weighted version of Ostrowski inequality for mappings of Hölder type and applications in numerical analysis, Bull. Math. Soc. Sci. Math. Romanie, 42 (90) (4) (1999), 301-314.

[25] S. S. Dragomir And S. FitzPatrick, The Hadamard inequalities for s-convex functions in the second sense, Demonstratio Math. 32 (1999), no. 4, 687-696.

[26] S. S. Dragomir AND S. FitzPATRICK, The Jensen inequality for s-Breckner convex functions in linear spaces, Demonstratio Math. 33 (2000), no. 1, 43-49.

[27] S. S. DRAGOMIR AND B. MOND, On Hadamard's inequality for a class of functions of Godunova and Levin, Indian J. Math. 39 (1997), no. 1, 1-9.

[28] S. S. Dragomir AND C. E. M. PEARCE, On Jensen's inequality for a class of functions of Godunova and Levin, Period. Math. Hungar. 33 (1996), no. 2, 93-100.

[29] S. S. Dragomir And C. E. M. Pearce, Quasi-convex functions and Hadamard's inequality, Bull. Austral. Math. Soc. 57 (1998), 377-385.

[30] S. S. Dragomir, J. PeČArić And L. Persson, Some inequalities of Hadamard type, Soochow J. Math. 21 (1995), no. 3, 335-341.

[31] S. S. Dragomir and Th. M. Rassias (Eds), Ostrowski Type Inequalities and Applications in Numerical Integration, Kluwer Academic Publisher, 2002.

[32] S. S. Dragomir AND S. WANG, A new inequality of Ostrowski's type in $L_{1}$-norm and applications to some special means and to some numerical quadrature rules, Tamkang J. of Math., 28 (1997), 239-244.

[33] S. S. DRAGOMiR AND S. WAng, Applications of Ostrowski's inequality to the estimation of error bounds for some special means and some numerical quadrature rules, Appl. Math. Lett., 11 (1998), 105-109.

[34] S. S. Dragomir ANd S. WANG, A new inequality of Ostrowski's type in $L_{p}$-norm and applications to some special means and to some numerical quadrature rules, Indian J. of Math., 40 (3) (1998), 245-304.

[35] A. El FARISSi, Simple proof and refeinment of Hermite-Hadamard inequality, J. Math. Ineq. 4 (2010), No. 3, 365-369.

[36] Abdallah El Farissi, Maamar Benbachir, Meriem Dahmane, An extension of the HermiteHadamard inequality for convex symmetrized functions, Real Anal. Exchange 38, 2 (2012/13), 467474.

[37] L. FEJÉR, Über die Fourierreihen, II, Math. Naturwiss. Anz Ungar. Akad. Wiss. 24 (1906), 369-390, (in Hungarian). 
[38] E. K. Godunova AND V. I. LEVIn, Inequalities for functions of a broad class that contains convex, monotone and some other forms of functions, (Russian) Numerical mathematics and mathematical physics (Russian), 138-142, 166, Moskov. Gos. Ped. Inst., Moscow, 1985.

[39] H. Hudzik And L. Maligranda, Some remarks on s-convex functions, Aequationes Math. 48 (1994), no. 1, 100-111.

[40] E. Kikianty And S. S. Dragomir, Hermite-Hadamard's inequality and the p-HH-norm on the Cartesian product of two copies of a normed space, Math. Inequal. Appl. 13, 1 (2010), 1-32.

[41] U. S. Kirmaci, M. Klaričić Bakula, M. E. ÖZdemir and J. PeČarić, Hadamard-type inequalities for s-convex functions, Appl. Math. Comput. 193 (2007), no. 1, 26-35.

[42] M. A. LATIF, On some inequalities for h-convex functions, Int. J. Math. Anal. (Ruse) 4 (2010), no. 29-32, 1473-1482.

[43] D. S. Mitrinović And I. B. Lacković, Hermite and convexity, Aequationes Math. 28 (1985), 229-232.

[44] D. S. Mitrinović And J. E. PeČARIĆ, Note on a class of functions of Godunova and Levin, C. R. Math. Rep. Acad. Sci. Canada 12 (1990), no. 1, 33-36.

[45] C. E. M. PeARCE AND A. M. Rubinov, P-functions, quasi-convex functions, and Hadamard-type inequalities, J. Math. Anal. Appl. 240 (1999), no. 1, 92-104.

[46] J. E. PEČARIĆ AND S. S. DRAGOMIR, On an inequality of Godunova-Levin and some refinements of Jensen integral inequality, Itinerant Seminar on Functional Equations, Approximation and Convexity (Cluj-Napoca, 1989), 263-268, Preprint, 89-6, Univ. "Babeş-Bolyai”, Cluj-Napoca, 1989.

[47] J. PEČARIĆ AND S. S. DRAgomir, A generalization of Hadamard's inequality for isotonic linear functionals, Radovi Mat. (Sarajevo) 7 (1991), 103-107.

[48] M. Radulescu, S. Radulescu And P. Alexandrescu, On the Godunova-Levin-Schur class of functions, Math. Inequal. Appl. 12 (2009), no. 4, 853-862.

[49] M. Z. SARIKAYA, A. SAGLAm, AND H. YILdirim, On some Hadamard-type inequalities for $h$ convex functions, J. Math. Inequal. 2 (2008), no. 3, 335-341.

[50] E. Set, M. E. Özdemir And M. Z. SARIKAYA, New inequalities of Ostrowski's type for s-convex functions in the second sense with applications, Facta Univ. Ser. Math. Inform. 27 (2012), no. 1, 67-82.

[51] M. Z. Sarikaya, E. SET And M. E. Özdemir, On some new inequalities of Hadamard type involving h-convex functions, Acta Math. Univ. Comenian. (N.S.) 79 (2010), no. 2, 265-272.

[52] M. TUnÇ, Ostrowski-type inequalities via h-convex functions with applications to special means, J. Inequal. Appl. 2013, 2013:326.

[53] S. VAroš Anec, On h-convexity, J. Math. Anal. Appl. 326 (2007), no. 1, 303-311. 